\title{
Relationship between Monetary Policy, Domestic Prices, Financial Development and Economic Growth: Evidence from Pakistan
}

Anam Bibi ${ }^{1}$, Syed Tahir Hussain Shah ${ }^{2}$, Syed Imran Rais ${ }^{3}$, Khalid Zaman $^{4 *}$, Abdul Mansoor $^{5}$, Shakira Ejaz ${ }^{6}$

${ }^{1,2,3}$ Department of Economics, University of Wah, Quaid Avenue, Wah Cantt, Pakistan. ${ }^{4,5,6}$ Department of Economics, University of Wah, Quaid Avenue, Wah Cantt, Pakistan.

*Corresponding Author: Khalid Zaman, Department of Economics, University of Wah, Quaid Avenue, Wah Cantt, Pakistan, E-mail: Khalid_zaman786@yahoo.com

\begin{abstract}
The objective of the study is to examine the relationship between monetary policy, domestic prices, financial development and economic growth in a context of Pakistan by using a consistent time series data from 1980 to 2016. The results show that real interest rate increases exchange rate that negatively influenced on country's economic growth, which confirmed that contractionary monetary policy is ineffective to stabilize country's economic growth. The trade linearization policies hurt Pakistan's economic growth, which invalidate the positive effect of globalization in developing countries. The inbound FDI has a positive impact on economic growth, whereas exchange rate and changes in price level both have a negative impact on inbound FDI in a country. The domestic saving rate substantially increases inbound FDI in a country. The positive impact of money supply on inflation confirmed the monetarist view of inflation, i.e., money supply leads to inflation. Thus, the overall conclusion confirmed the sound viability of expansionary monetary policy in a given country for sustained growth.
\end{abstract}

Keywords: Real Interest Rate; Exchange Rate; Broad Money Supply; Trade Openness; FDI Inflows; External Debt; Pakistan.

\section{INTRODUCTION}

Monetary arrangement includes the impact on the level and structure of total interest by the control of financing costs and the accessibility of credit. Classical investigations measure that economic development is generally connected to the factors of production. The development of the endogenous development theory has insisted authorities to search the part of different factors in clarifying the development phenomenon (Barro 1991, Levine 1999). Analysts and different investigators for the most part concur that monetary activities made by policy makers importantly affect the economy. Despite of endless difficulties, Pakistan's economy has been developed, yet not as much to be counted in the developed countries of the world. There are a few imperfections going about as an obstacle in the way for getting into the developed countries of world like inflation, income disparities and lower rate of employments (Economic Survey of Pakistan, 2017). 
Monetary policy is a significant apparatus for accomplishing stable level of prices, brings an appropriate change amid the demand and supply of cash. Unevenness among the two will be returned in the price level. A nonexistence of money supply will delay the development while an abundance of it wills speedy inflation. As the economy builds up, the demand for cash increments because of the progressive monetization of the non-monetized sector, and the expansion in farming and industrial production. These will speedy addition in the demand for transactions and speculative motives. So the monetary expert should collect the cash supply more than equivalent to the demand for cash so as to stay away from high level of prices (Goodhart, 1989).

The previous literature widely provoked the effectiveness of monetary policy in different economic settings, i.e., Van Wijnbergen (1982) presented a three-monthly macroeconomic prototypical of South Korea that expressly consolidates adapted certainties' about Korea's monetary structure. The model spotlights on the linkage amongst money related and genuine area and expressly consolidates the spread network of fiscal arrangement into the supply side of the economy through the genuine prices occupied resources. The econometric confirmation demonstrates the pertinence of this impact. Reenactment keeps running with the model in view of the assessed parameter esteems demonstrate solid stagflationary impacts of prohibitive money related approach in the short run as a result of this transmission channel. Mussa (1977) considered the expansion of the basic criteria of the monetary way to deal with adjustment of BoP investigation to an establishment of uncontrolled exchange rates, with dynamic mediation by the specialists to control rate actions. It makes four primary focuses. To begin with, the conversion standard is the relative cost of various national monies, as opposed to country's output, and is settled in a general sense by the desire and supplies of lots of different national monies. Second, exchange rates are unequivocally affected by asset holder's wants of future exchange rates and these wants are influenced by feelings regarding the future passage of money related arrangement. Third, "genuine" components, and in addition financial variables, are essential in deciding the conduct of exchange rates. Fourth, the issues of strategy strife which exist under an arrangement of settled rates are decreased, yet not disposed of, under an administration of controlled floating.

Crespo-Cuaresma et al., (2016) investigated the communication between monetary approach in the US and the worldwide economy, utilizing a worldwide vector autoregressive model (VAR) with timechanging parameters and stochastic unpredictability. They found contractionary US money related strategy surprise prompts an insistent fall in worldwide output, a drop in worldwide cost rates (inflation), an ascent in international interest rate and a consolidation of the US dollar in real terms, with heterogeneous transmission impacts crosswise over nations and after some time. US short-term rates diminish fundamentally because of a monetary strategy fixing abroad or a negative shock to outside genuine GDP growth. Bernanke and Gertler (2000) found the consequences of resource price instability for the administration of monetary policy. Their work is according of US and Japanese monetary policy. It is essential for central banks to accentuation on basic inflationary pressure. Asset price converted applicable solitary to the level they may flag probable inflationary or deflationary forces. Standards that specifically target asset prices seem to have troublesome reactions.

A financial business cycle display with ordinary loans and insurance limitations secured to housing values, created and assessed by lacoviello (2005). As indicated by lacoviello, demand stuns move lodging and ostensible costs a similar way, and are amplified and engendered after some time. The financial quickening agent isn't uniform: ostensible obligation hoses supply stuns, balancing out the economy under loan fee control. Auxiliary estimation bolsters two key model highlights: guarantee impacts significantly enhance the reaction of total request to lodging value stuns; and ostensible obligation enhances the lazy reaction of yield to inflation shocks. At long last, strategy assessment considers the part of house costs and obligation indexation in influencing money related arrangement exchange offs. Erceg et al. (2000) defined an optimizing-agent model in which both employment and item markets show monopolistic rivalry and stunned nominal contracts. The unqualified desire of normal household utility can be communicated as far as the unqualified adjustments of the output gap, value expansion (inflation), and wage inflation. Monetary policy can't accomplish the Pareto-optimal equilibrium that would happen 
under totally adaptable wages and costs, that is, the model displays a tradeoff in balancing out the output gap, value expansion, and wage inflation. They portrayed the ideal optimal policy rule for sensible alignments of the model. Likewise found that strict inflation focusing on creates moderately extensive welfare sufferers, while a few other basic approach rules perform almost and in addition the ideal rule.

Hassan et al. (2017) investigated factors that influence trade discrepancy. In the wake of applying ARDL limits testing approach on test period from 1972 to 2013, they discovered proof of long run connection between trade discrepancy and its components in Pakistan, India and Bangladesh. The discoveries affirm that deterioration of genuine successful exchange rate essentially diminishes trade deficiency in Pakistan and Bangladesh. In addition, the outcomes additionally unveil that as economic development grows, trade deficiency shortens altogether in Pakistan, India and Bangladesh. The discoveries likewise demonstrate that money supply essentially improves trade deficits in Pakistan and India. These discoveries are powerful to different demonstrative tests which are utilized as a part of the examination. At last in light of these outcomes, it is inferred that trade deficiency could be enhanced by focusing on genuine successful exchange rate, per capita income and money supply in Pakistan, India and Bangladesh. Ratnasari and Widodo (2017) examined the relationship between Exchange Market Pressure (EMP) and financial policies in ASEAN5 (Indonesia, Malaysia, the Philippines, Thailand, and Singapore). This examination applies Vector Error Correction Model (VECM) and month to month information for the periods January 2006 _ December 2016 for singular nation estimation. The outcomes demonstrate that the ASEAN5 monetary specialists have reacted the expansion of EMP by contracting national credit in the non-crises periods, and by giving greater liquidity to the bank framework in the emergency or crises time frames. What's more, on account of ASEAN5 the expansion in interest rate differential has lessened the EMP.

\section{RESEARCH QUESTIONS}

The following are the research questions of the study, i.e.,

1. Does monetary policy have significant impact on economic growth?

2. Does monetary policy raises the existing price level in the country?

3. Whether monetary policy helps to reduce external debt? And

4. To what extent monetary policy stabilizes exchange rate of domestic currency?

These questions required extensive empirical exercise for sound inferences in a given country.

\section{Objective Of The Study}

The objectives of the study is as follows, i.e.,

1. To examine the impact of interest rate, exchange rate, trade openness, and FDI inflows on country's economic growth.

2. To examine the impact of exchnagre rate, inflation, and domestic saving on inbound FDI in a country.

3. To analyze the role of interest rate, exchange rate, broad money supply, and domestic credit on price level in a country.

4. to investigate the impact of interest rate and exchange rate on external debt, and

5. To examine the impact of interest rate, domestic credit, and price level on exchange rate in a country.

6.

SIGNIFICANCE OF THE STUDY

To keep up the price dependability, state bank of any nation endeavors to control the currency supply of that nation. In this manner, monetary arrangement assumes its part to balance out the financial 
development through the quantity of channels. Monetary policy plays an important role in raising economic growth in LDCs, because it can control the high level of prices. It also has influence on employment, exchange rate, trade and investment. So it plays vital role for the development of countries. This study is conducted to investigate the linkages among monetary policy, financial development, domestic prices and economic growth by using five different models, which is imperative for sound policy inferences.

\section{METHODOLOGY}

\section{THEORETICAL FRAMEWORK}

The study used different variables on the basis of previous given literature, for example, Anwar et al., (2016) assessed the effect of financial approach on the economy of Pakistan in the light of Monetarist and Keynesian perspectives. For analysis, they used real exchange rate, $\mathrm{M}_{2}$ and consumer price index as independent variables. Habib et al. (2017) considered the influence of actions in the real exchange rate on economic growth. They used many variables like real exchange rate, interest rate, consumer price index, saving, trade and foreign direct investment for policy inferences. As indicated by them, for setting up the best financial arrangement it is basic to know whether by and by money related factors decide total national output (GDP) in consistent costs. For an arrangement of more financial factors, they recognized that $M 2, M 3$ and also internal credit were firmly connected for GDP. Therefore, our study used these variables namely, GDP, interest rate, exchange rate, CPI, FDI, trade $\mathrm{M}_{2}$, savings, debt and domestic credit to private sectors (DCPS), for investigating the relationship between these (above mentioned) independent variables and dependent variable.

The study has developed the following equations for estimation

$G D P=\beta+\beta_{1} I R_{+} \beta_{2} E X R_{+} \beta_{3} F D I+\beta_{4} T+€$

Where:

GDP is presenting Gross Domestic Product (proxy for economic growth), IR used for Interest Rate, EXR for Exchange rate, FDI for Foreign Direct Investment, TOP represents trade openness. The study used GDP as dependent variable and interest rate, exchange rate, foreign direct investment, and trade as independent variables. If interest rate is low more people are able to borrow more money, causing economy to grow. Exchange rate is low so imports are more and growth will be low. Trade should be positively related with the GDP of a country. FDI raises the economic growth as it brings technological advancements in the country. The equation (2) is as follows:

$F D I=\beta+\beta_{1} I R_{+} \beta_{2} E X R_{+} \beta_{3} C P I_{+} \beta_{4} S+\beta_{5} T+€ \ldots$

2

Here saving is denoted by $\mathrm{S}$ and $\mathrm{CPI}$ is presenting Consumer price Index

In $2^{\text {nd }}$ equation FDI is dependent on IR, EXR, CPI, saving and trade. Interest rate and trade should positively relate with the FDI as it appeals more FDI inflows in the country. Exchange rate and inflation are negatively related with FDI as the FDI inflow stabilizes the exchange rate value and inflation. Equation (3) is as follows:

$C P I=\beta+\beta_{1} I R+\beta_{2} E X R+\beta_{3} M 2+\beta_{4} D C P S+€ \ldots$

Where, $\mathrm{M}_{2}$ shows broader money supply and DCPS shows domestic credit to private sector.

In the $3^{\text {rd }}$ equation CPI (inflation) is dependent variable and IR, EXR, DCPS and money supply are independent variables. Appreciation of a currency depends on the growth prospects of an economy and also the level of uncertainty in the world economy. Level of inflation, depends on money available in the system. more cash supply prompts an expansion in high prices. To control this we increment borrowing cost. Rate climb weakens mixture of more cash in the framework and consequently prices begin to 
diminish. Inflationary condition smashes budgetary advancement through limiting financial assets for speculation schemes. The equation (4) is as follows:

Debt $=\beta+\beta_{1} I R+\beta_{2} E X R_{+} \beta_{3} F D I+\beta_{4} T+€$

4

Where, Debt shows external debt.

In this equation, debt is dependent variable and IR, EXR, FDI and trade are taken as explanatory variables. Higher interest rate reduces the net asset value of funds, resulting lower returns for the debt investors. FDI, EXR and trade has negative impact on debt as shows the high level of growth and when the level of growth is high there is a low level of debt. The equation (5) is as follows:

$E X R=\beta+\beta_{1} I R+\beta_{2} M_{2+} \beta_{3} C P I_{+} \beta_{4} D C P S+\beta_{5} T+€$

5

In the last equation EXR is explained by IR, CPI, DCPS, trade and money supply. IR, CPI, money supply and trade should have negative impact on EXR but EXR is positively related with financial development.

\section{LIST OF VARIABLES}

Following are the list of variables that are used in this study to evaluate the linkages between monetary policy, financial development, Domestic prices and Economic growth for the country of Pakistan. Table 1 shows list of dependent and independent variables with their expected signs.

Table 1: List of Variables

\begin{tabular}{|c|c|c|}
\hline Variables & Symbols & Measurement Scale \\
\hline Gross domestic product & GDP & constant 2010 US\$ \\
\hline Foreign direct investment & FDI & $\%$ of GDP \\
\hline Consumer price index & $\mathrm{CPI}$ & $2010=100$ \\
\hline Debt (external debt) & Debt & current US\$ \\
\hline Exchange Rate & EXR & $\begin{array}{l}\text { Real effective exchange rate index } 2010= \\
100)\end{array}$ \\
\hline $\begin{array}{l}\text { Interest Rate (Average interest on new } \\
\text { external debt commitments) }\end{array}$ & IR & $\%$ of GDP \\
\hline Trade & $\mathrm{T}$ & $\%$ of GDP \\
\hline Saving & $\mathrm{S}$ & $\begin{array}{l}\text { Adjusted savings: consumption of fixed } \\
\text { capital (current US } \$ \text { ) }\end{array}$ \\
\hline Broader Money Supply & $\mathrm{M}_{2}$ & $\%$ of GDP \\
\hline Domestic credit to private sector by banks & DCPS & $\%$ of GDP \\
\hline
\end{tabular}

\section{DATA SOURCE}

The study used secondary data of variables for the country of Pakistan that is taken from WDI published by World Bank (2017) for the period of 1980-2016. To find the empirics of the study we used E-Views 9 software.

\section{HYPOTHESIS DEVELOPMENT}

The study developed the following key hypothesis for the study, i.e.,

$\mathrm{H}_{1}$ : Interest rate has a positive impact on economic growth to support expansionary monetary policy.

$\mathrm{H}_{2}$ : There is a positive relationship between CPI, IR and financial development.

$\mathrm{H}_{3}$ : Interest rate and debt has positive relationship and

$\mathrm{H}_{4}$ : There is a positive relationship between exchange rate and interest rate 


\section{ECONOMETRIC FRAMEWORK}

In order to study the relationship between the stated variables, we used Two stage least squares (TSLS) regression apparatus for robust inferences. .

\section{Two-Stage Least Squares (TSLS) Regression}

Two-Stage Least squares (2SLS) regression analysis is a measurable procedure that is utilized as a part of the examination of basic equations. This system is the expansion of the OLS strategy. It is utilized when the stated variable's residuals are associated with the autonomous factors. Also, it is helpful when there are input circles in the model. In structural equations modeling, we utilize the maximum likelihood method to estimate the path coefficient. This strategy is an option in simultaneous equations modeling demonstrating to evaluate the way coefficient. This system can likewise be connected in semi exploratory investigations

\section{RESULTS AND DISCUSSION}

Figure 1 shows the plots of level data for ready reference. GDP and consumer price index is rising over the time, while debt, DCPS, exchange rate, foreign direct investment and trade are fallen down. Debt is falling from 2015, domestic credit to private sector is falling down from 2010, and exchange rate is falling from 1984 to 1990 very rapidly then from 1990 to 1995 it become stable with small ups and downs. Foreign direct investment rises rapidly from 2003 to 2007 and then it declines rapidly from 2007-12. Saving has small fluctuation but it is increasing overtime. trade's data explains that it has fluctuation but it decline very fast in the years of 2000-13 after that it increases but slowly and declines in 2012.Interest rate has fluctuated but declining behavior over the time. On the other hand broad money supply $\left(M_{2}\right)$ is in increasing behavior with fluctuations but in the time period of 2000-04 and 2005-07 it rises rapidly.

CPI

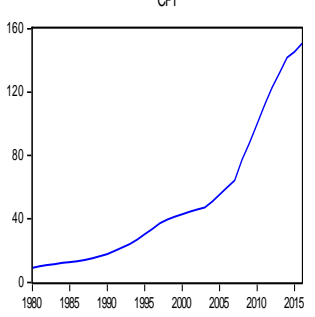

$\mathrm{FDI}$

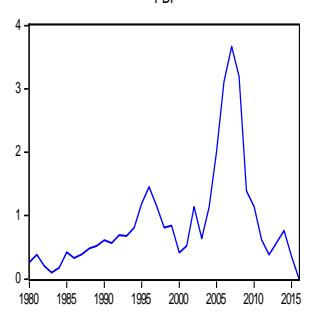

SAVING

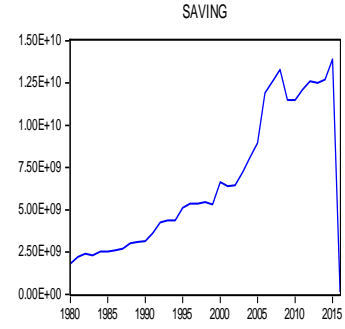

DEBT

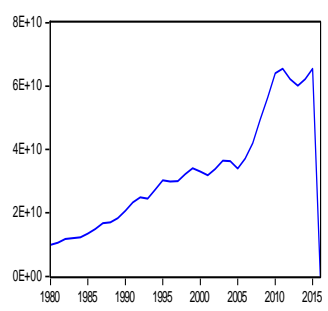

GDP
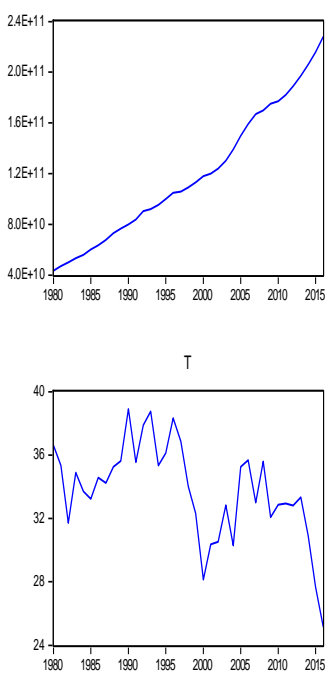

DCPS

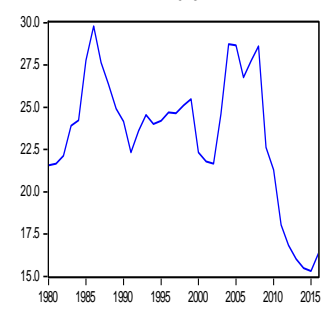

$\mathbb{R}$

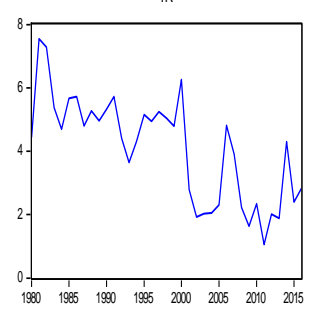

EXR

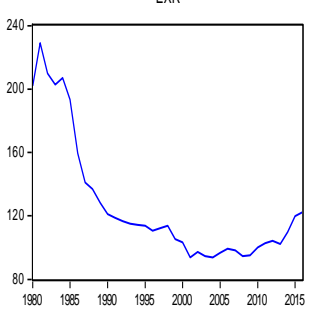

M2

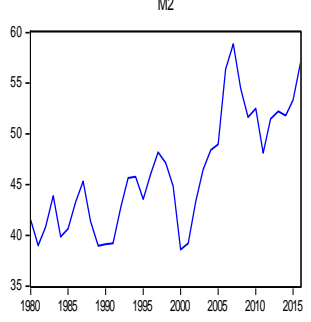

Figure 1: Plots of Level Data

Source: World Bank (2017). 
Table 2 shows the descriptive statistics of the variables. The mean value of CPI Debt, DCPS, EXR, FDI, GDP, IR, M2, saving and trade is 51.3, 3.20, 23.39, 126.47, 0.89, 1.19, 4.08, 46.2, 6.48 and 33.74 respectively. The minimum and maximum value of consumer price index is 9.11 and 150.75 respectively, for debt 0.00 and 6.55, for domestic credit to private sector 15.30 and 29.78 , for exchange rate 93.7 and 229.1, for foreign direct investment minimum and maximum values are 0.0 and 3.6, for interest rate 1.06 and 7.54, for broad money supply (M2) 38.5 and 58.8 and for saving and trade minimum and maximum values are $0.0,1.39$, and 25.1 and 38.9 respectively. The standard deviation is the square root of variance which provides variability in distribution of scores. In the table the value of standard deviation of all variables is close to the mean values of variables. According to statistics of sequences, the domestic credit to private sector, interest rate and trade are negatively sequined with the sequence value $-0.58,-0.034$ and -0.64. kurtosis explain the normal distribution of data as table values shows that $\mathrm{CPI}$, domestic credit to private sector, trade and exchange rate are closer to 3 as their values are 2.91, 2.71, 3.48, 3.69 respectively. Descriptive statistics don't empower us to effect ends previous statistics we have inspected or accomplish ends in respects to any speculations we may have made. They to make conclusion we find correlation and apply two stage least square test (TSLS) to analyzed the data regarding hypothesis.

Table 2: Descriptive Statistics

\begin{tabular}{lllllll}
\hline Variables & Mean & Maximum & Minimum & Std. Dev. & Skewness & Kurtosis \\
\hline CPI (Index 2010=100) & 51.31 & 150.75 & 9.11 & 43.33 & 1.08 & 2.92 \\
DCPS (\% of GDP) & 23.40 & 29.79 & 15.31 & 3.88 & -0.58 & 2.71 \\
EXR (Index 2010=100) & 126.47 & 229.15 & 93.78 & 39.01 & 1.44 & 3.70 \\
DEBT (US \$, in billions) & 33.800 & 65.50 & 9.93 & 18.00 & 0.54 & 2.11 \\
FDI (\% of GDP) & 0.91 & 3.67 & 0.10 & 0.84 & 2.05 & 6.59 \\
GDP (US \$, in billions) & 11.90 & 22.80 & 43.40 & 53.00 & 0.39 & 2.02 \\
IR (\% of GDP) & 4.09 & 7.55 & 1.06 & 1.66 & -0.03 & 2.11 \\
SAVING (US \$, in billions) & 68.60 & 13.90 & 1.80 & 4.15 & 0.48 & 1.68 \\
T (\% of GDP) & 33.75 & 38.91 & 25.14 & 3.06 & -0.65 & 3.49 \\
M2 (\% of GDP) & 46.21 & 58.87 & 38.59 & 5.75 & 0.46 & 2.21 \\
\hline
\end{tabular}

Table 3 shows the correlation matrix for ready reference. The correlation matrix deals with the power and way of a lined affiliation among two variables. The value of correlation is closest to or exactly 1 then there is a perfect linear relationship. Its negative sign shows that the relationship is inverse negative or positive between variables. As our results shows that consumer price index has a linear relationship with economic growth with the coefficient value 0.95 that shows as prices increases, economic growth rises. Exchange rate and interest rate are negatively correlated with GDP, as higher interest rate shows free monetary policies have not well enough effect on growth (GDP). The negative sign of trade coefficient (-0.53) explains that in Pakistan due to trade deficit if trade rises economic growth (GDP) declines. The correlation matrix shows that consumer price index, savings and trade are positively correlated with foreign direct investment with the coefficient values are $0.20,0.51$ and 0.10 respectively. The exchange rate and interest rate are negatively correlated with FDI by the values respectively -0.48 and -.25 . Higher exchange rate is less attractive to the foreigners that will decrease the foreign direct investment. As trade is high and trade deficit is less, is more attractive to the foreigner that raises the foreign direct investment. Interest rate, exchange rate and domestic credit to private sector are negatively correlated with consumer price index but $\mathrm{M} 2$ is positively correlated with consumer price index by the coefficient values are $-0.49,-0.66,-0.68$ and 0.75 respectively. The correlation test results explains that interest rate, exchange rate and trade are negatively correlated with debt but foreign direct investment is positively correlated with debt as the coefficient values shows $-0.64,-066,-0.22$ and 0.28 
respectively. The consumer price index and $\mathrm{M} 2$ are positively correlated with exchange rate while interest rate, domestic credit to private sector and trade are negatively correlated with exchange rate.

Table 3: Correlation Matrix

\begin{tabular}{|c|c|c|c|c|c|c|c|c|c|c|}
\hline Variables & $\mathrm{CPI}$ & DEBT & DCPS & EXR & FDI & GDP & IR & M2 & SAVING & TOP \\
\hline CPI & 1.000000 & & & & & & & & & \\
\hline DEBT & 0.731109 & 1.000000 & & & & & & & & \\
\hline DCPS & -0.68672 & -0.4069 & 1.000000 & & & & & & & \\
\hline EXR & -0.49493 & -0.6411 & 0.050164 & 1.000000 & & & & & & \\
\hline FDI & 0.122413 & 0.342197 & 0.423976 & -0.47145 & 1.000000 & & & & & \\
\hline GDP & 0.957825 & 0.765939 & -0.51062 & -0.68104 & 0.341032 & 1.000000 & & & & \\
\hline IR & -0.66956 & -0.66485 & 0.285201 & 0.633288 & -0.23066 & -0.73519 & 1.000000 & & & \\
\hline M2 & 0.759125 & 0.577816 & -0.19078 & -0.49754 & 0.580486 & 0.829160 & -0.57747 & 1.000000 & & \\
\hline SAVING & 0.718534 & 0.945067 & -0.27729 & -0.61804 & 0.560112 & 0.793177 & -0.6472 & 0.700254 & 1.000000 & \\
\hline TOP & -0.58139 & -0.22706 & 0.452779 & 0.144610 & 0.192846 & -0.53689 & 0.319405 & -0.28799 & -0.23006 & 1.000000 \\
\hline
\end{tabular}

Table 4 shows the estimates of equation (1) for ready reference. The results show that interest rate has a significant but inverse relationship with the GDP. The results are consistent with past investigations of Anaripour (2011) and D'Adda \& Scorcu (1997) who found the negative connection among development and increasing interest rates. This outcome is in concurrence with the predictable perspective of a long run positive connection among development and capital collection and a negative long run interface among accumulation and the expense of capital. Additionally the result is in accordance with the view that connections the slower development of the manufacturing nations in the course of the most recent decades appears to the execution of prohibitive monetary approaches. There is negative connection between interest rate and development and this relationship is a one-sided causal connection between the development and interest rate in factual view (Anaripour, 2011).

Table 4: TSLS Estimates for Equation (1)

\begin{tabular}{lllll}
\hline Variable & Coefficient & Std. Error & t-Statistic & Prob. \\
\hline $\mathrm{C}$ & $4.45 \mathrm{E}+11$ & $5.23 \mathrm{E}+10$ & 8.497517 & 0.0000 \\
$\mathrm{IR}$ & -0.41 & $3.69 \mathrm{E}+09$ & -3.217191 & 0.0030 \\
EXR & -0.42 & $1.67 \mathrm{E}+08$ & -2.335756 & 0.0259 \\
FDI & 0.10 & $6.40 \mathrm{E}+09$ & 2.063730 & 0.0472 \\
$\mathrm{~T}$ & -2.01 & $1.62 \mathrm{E}+09$ & -4.384931 & 0.0001 \\
$\mathrm{R}^{2}$ & 0.765922 & F-statistic & 26.17670 \\
Adjusted R & 0.736663 & Prob(F-statistic) & 0.000000 \\
\hline
\end{tabular}

Exchange rate has a negative effect on GDP that shows higher exchange rate deteriorate GDP which needs substantial economic policies to balance country's GDP in terms of US\$. Our results are consistent of previous studies of Habib et al. (2017), Edwards (1996) and Rodrik (2007) confirmed the negative impact of interest rate on GDP and conclude that the real exchange rate has significantly negative impact on real per capita GDP growth. The impact is more grounded for developing nations (instead of advanced edge) and for pegs (as opposed to floats). The less adaptable exchange rate regimes are related with slower development in developing nations. Their confirmation recommends rather that, on the off chance that anything, it is critical to peg at the ideal time, on the grounds that after some time notwithstanding pegging nations do not control their real exchange rate. Edwards (1996) clarified that the assessed coefficient of the rate of development of GDP is suggestively negative showing that, with different things given; nations with a lower development rate will have a tendency to favor a more inelastic exchange-rate administration. Real exchange-rate devaluations would encourage limit 
development in tradable and increment development. Note that by and by, this is a moment best contention for undervaluation. To begin with best approach would comprise of recognizing particular market disappointments and applying the suitable Pigovian cures. Undervaluation is a substitute for modern approach (Rodrik, 2007).

Trade has negative relationship with GDP because in case of Pakistan, our imports are more than exports that shows our currency is moving outward more than its coming in our country that deteriorate growth which needs substantial economic policies to balance country's growth in terms of US\$. Our results are consistent of previous studies of Bleaney and Greenway (2001) and Hye and Lau (2015) confirmed the negative impact of interest rate on economic growth. According to Bleaney and Greenway (2001) economic growth is negatively affected by trade because of instability of terms of trade. If the terms of trade improve then growth will increase. Trade openness record adversely impacts on development over the long haul. Foreign direct investment (FDI) has a positive relationship with GDP. The result shows that increase in FDI will raise the GDP growth. The result explains that rise in FDI will appreciate GDP. Foreign direct investment positively effects economic growth. This positive affiliation holds internationally as powerfully as in developing nations. Facilitate it is provincial variety instead of inside nation variety, and concurrent FDI as opposed to past FDI, which matters for development (lamsiraroj and Ulubasoglu, 2015). FDI is related with higher rates of economic development (GDP). They are reliably for huge additions to a host nation from appealing FDI. Investment streams and the exertions should be taken to accomplish more elevated amount of FDI. The host nation's policymakers should try to quicken the nation's financial development which will bring about higher FDI inflows. The investment specialists ought to likewise guarantee that the streams of FDI is energized into the nation solidity as it could impact financial development and balance out monetary development from the effect of critical swings. Table 5 shows the estimates of equation (2) for ready reference.

Table 5: TSLS Estimates for Equation (2)

\begin{tabular}{lllll}
\hline Variable & Coefficient & Std. Error & t-Statistic & Prob. \\
\hline C & -0.353834 & 1.719087 & -0.205827 & 0.8383 \\
IR & 0.351 & 0.095882 & 0.827149 & 0.4145 \\
EXR & -0.887 & 0.003685 & -1.754698 & 0.0892 \\
CPI & -0.481 & 0.004599 & -1.878168 & 0.0698 \\
SAVING & 1.214 & $4.22 E-11$ & 3.991588 & 0.0004 \\
T & 1.189 & 0.044252 & 0.734462 & 0.4682 \\
R $^{2}$ & 0.533666 & F-statistic & & 7.095206 \\
Adjusted $R^{2}$ & 0.458451 & Prob(F-statistic) & & 0.000159 \\
\hline
\end{tabular}

Note: Dependent variable: FDI.

The results show the negative impact of inflation (CPI) on foreign direct investment with the small coefficient value. According to Taylor (2000) wages and inflation measures are negatively related with foreign direct investment. Asiedu (2002) concluded that low inflation rates promote and stimulate FDI into the region. The negative linkage between these two variables captures the important role of macroeconomic conditions in a particular region. The advantage of financing would fall in case of rising inflation as it dissolves obtaining intensity of purchasers in the host nation. Most of the experimental investigations have discovered that high price level affects FDI Inflows in any particular country. It implies that the role of government to improvise the macroeconomic balancing out approaches is essential keeping in mind the end goal to pull in and encourage more FDI inflows. The results show that saving has a positive relation with foreign direct investment. Our results confirm by other researchers that found positive impact of savings on foreign direct investment. Bosworth et al. (1999) and others explained that FDI seems to produce vast increments in domestic saving, with no negative ramifications for the outdoor balance, however the outcomes were not vigorous to elective determinations. Alguacil et al. (2004) clarify that higher saving prompts higher financial development. The affirmation of a saving development nexus in the nation is by all accounts identified with the incorporation of FDI in the model, as the most important 
segment of outside saving. As this examination appears, this last factor upgrades financial development. Table 6 shows the estimates of equation (3) for ready reference.

Table 6: TSLS Estimates for Equation (3)

\begin{tabular}{lllll}
\hline Variable & Coefficient & Std. Error & t-Statistic & Prob. \\
\hline C & 45.45522 & 32.05905 & 1.417859 & 0.1659 \\
IR & -0.291 & 1.935762 & -1.885109 & 0.0685 \\
M2 & 3.485 & 0.481600 & 8.034514 & 0.0000 \\
DCPS & -2.762 & 0.603194 & -10.04037 & 0.0000 \\
EXR & -0.338 & 0.075980 & -1.807210 & 0.0801 \\
$R^{2}$ & 0.917229 & F-statistic & 88.65215 \\
Adjusted R ${ }^{2}$ & 0.906883 & Prob(F-statistic) & 0.000000 \\
\hline \multicolumn{4}{c}{ Note: Dependent variable: CPI }
\end{tabular}

The result of this model displayed that inflation rate can be enlarged by accumulative broad money supply $\left(\mathrm{M}_{2}\right)$. It can also increase by declining the interest rate or by exchange rate depreciation. Exchange rate has a negative relationship with $\mathrm{CPI}$. Interest rate, DCPS and Exchange rate has negative relationship with $\mathrm{CPI}$ but $\mathrm{M}_{2}$ (broad money supply) has positive impact on CPI. . (We have shown the value of coefficients after converting the real values into elasticity value). Results are also significant statistically like the other researchers, like Fama \& Gibbons (1982) clarifies the negative relations amongst CPI and genuine profits for financial assets are persuaded by a perception about the money supply process throughout the post-1953 period, specifically, the way that the majority of the variety in genuine cash requested because of variety in genuine action has been obliged through counterbalancing variety in costs instead of through ostensible money development. Fama and Schwert (1997) found the strangest outcome is that regular stock returns were adversely identified with the normal part of the inflation rate, and likely likewise to the unforeseen segment. Miller et al. (1976) found the negative connection between two factors and said that the market may be wasteful in appropriating accessible data about future inflation into stock costs. The result of TSLS test shows negative impact of exchange rate on consumer price index (CPI/ inflation). McCarthy (2007) shows the reaction of the CPI to the exchange rate surprise is littler than that of the PPI (producer price index), and is factually fundamentally negative Furthermore, various reactions have the wrong (positive) sign, especially in Japan and France. Once more, the exemptions to this pattern are Belgium and the Netherlands. The pass-through in the US is for the passthrough to the consumption price deflator.

The result explains the positive relation between $\mathrm{CPI}$ and $\mathrm{M}_{2}$. The results are consistent with previous researchers' studies. Like Grauwe \& Polan (2005) shows that in the class of less-inflation nations, money development and speed changes are conversely related, while in the class of high-inflation nations the turnaround holds, i.e., money development and speed development are decidedly related. The coefficients of money development increment with the level of inflation, for all levels of time total expands the estimation of the coefficients of $\mathrm{m} 1$ and $\mathrm{m} 2$ for low-inflation nations. While moving from one-yearly average to three-yearly midpoints, we see that the coefficients of low-inflation nations increment. $\mathrm{M}_{2}$ is positively related for short lags but negatively correlated for longer lags (Ratanapakorn $\&$ Sharma 2007). Money supply that expansion total request in the economy is likewise anticipated that would have beneficial outcome on all pointers of inflation. M2 supply of money will influence every one of the markers of inflation emphatically. Financial indicator, i.e., DCPS is negatively related with inflation (CPI). Inflationary environment deteriorate the financial development through restricting financial resources for investment projects. The results are significant wit the previous study of Greene and Villanueva (1991) found that a higher price level negatively affected private speculation for 23 developing nations in their pooled time series/cross-sectional investigation. In low wage nations Credit to the private segment, residential inflation rate are corresponded and generally effect on private speculation rates in low-wage nations. Table 7 shows the estimates of equation (4) for ready reference. 
Table 7: TSLS Estimates for Equation (4)

\begin{tabular}{lllll}
\hline Variable & Coefficient & Std. Error & t-Statistic & Prob. \\
\hline C & $8.07 \mathrm{E}+10$ & $2.52 \mathrm{E}+10$ & 3.201107 & 0.0031 \\
IR & -0.564 & $1.77 \mathrm{E}+09$ & -2.558757 & 0.0154 \\
FDI & 0.0667 & $3.07 \mathrm{E}+09$ & 0.774869 & 0.4441 \\
T & -0.422 & $7.88 \mathrm{E}+08$ & -0.521459 & 0.6056 \\
EXR & -0.557 & 80265059 & -1.809768 & 0.0797 \\
R-squared & 0.533082 & F-statistic & 9.133621 \\
Adjusted R-squared & 0.474717 & Prob(F-statistic) & 0.000049 \\
\hline
\end{tabular}

Note: Dependent variable: DEBT

The results show that interest rate and exchange rate has negative impact on debt. Results show that debt rate can be declined by growing interest rate or by exchange rate appreciation. (We have shown the value of coefficients after converting the real values into elasticity value and we the complete results are given in appendix here we just explained the significant results of TSLS for $4^{\text {th }}$ model). Our result shows that exchange rate and interest rate has a significant inverse relationship with debt rate. Results are also significant statistically like the other researchers like Allayannis et al. (2001) and Goldfajn (2000) and concluded that that if firms utilize cash holdings or foreign debt as a fence, at that point we ought to expect a negative connection between the utilization of budgetary supports and exchange rate chance. Allayannis et al. (2001).discovered a negative connection between exchange rate presentation and budgetary supports, demonstrating that organizations utilize cash subordinates and outside obligation as fences. As indicated by Goldfajn (2000) foreign designated debt ought to be contrarily identified with the difference of the real exchange rate. With a large offer of foreign named debt relying upon whether the covariance amongst inflation and the genuine exchange rate is negative. On the off chance that the profits cover adversely, the bonds are supplements in the administration's portfolio and they should increment relatively.

The results show the negative impact of interest rate on debt. The results are followed by previous studies. The main sort of reserve funds (saving) that increased was foreign investment funds, i.e. external debt. This, nevertheless, made the 'liberalized' economies more helpless against fluctuations in the universal economy, expanding the debt resource proportion and subsequently benefits commitments and advancing the debt emergencies experienced in the current past (Arestis \&Demetriades, 1997). According to Barclay and Smith (1995) there is an adverse relationship amongst currency-price hedging and debt maturity. Hypothetically, firms whose cash flow sensitivity to interest rates is adverse ought to essentially desire reverse fluctuating rate debt instrument, if their impartial is to hedge (reducing risk of losing money on shares and bonds etc). On the off chance that organizations are hedging, at that point the outcomes ought to be that organizations that are all the more decidedly presented to interest Hedging or Market Timing (which means their income rises when loan costs/ interest rate rise) should have their advantage installments emphatically related with financing costs. In this manner, as firm financing cost introduction builds, its inclination for floating rate debt should increment (Faulkender, 2005). Table 8 shows the estimates of equation (5) for ready reference.

Table 8: TSLS Estimates for Equation (5)

\begin{tabular}{|c|c|c|c|c|}
\hline Variable & Coefficient & Std. Error & t-Statistic & Prob. \\
\hline C & 266.4335 & 91.86801 & 2.900177 & 0.0068 \\
\hline IR & 0.2803 & 4.212136 & 2.060394 & 0.0478 \\
\hline $\mathrm{M}_{2}$ & 0.7850 & 1.933658 & 1.112317 & 0.2746 \\
\hline DCPS & -1.122 & 2.579153 & -2.351597 & 0.0252 \\
\hline CPI & -0.372 & 0.419189 & -2.188992 & 0.0363 \\
\hline $\mathrm{T}$ & -0.687 & 2.081875 & -1.235999 & 0.2257 \\
\hline R-squared & 0.521928 & \multicolumn{2}{|c|}{ F-statistic } & 6.768771 \\
\hline Adjusted R-squared & 0.444820 & \multicolumn{2}{|c|}{ Prob(F-statistic) } & 0.000227 \\
\hline
\end{tabular}


The results show that exchange rate is negatively related with DCPS (financial indicator) and CPI (Inflation). But has a positive relationship with interest rate. Adjusted $\mathrm{R}^{2}$ displays that just $44 \%$ variation from the total in exchange rate is triggered by the instructive variables of the model. Result of above model shows that exchange rate can be increased by decreasing CPI inflation rate. It can also increase by declining domestic credit to private sector (DCPS financial indicator). Results are consistent with previous studies of Asari et al. (2011) they found a positive connection between the exchange rate and the nominal interest rate. There is a negative connection between financing cost and exchange rate. i.e., a high financing cost strategy is related with exchange rate appreciation. Be that as it may, the spot exchange rate may be influenced directly by the high loan fee approach when the predictable exchange rate turns into an expanding capacity of the domestic financing costs (Dash, 2012). As indicated by Aizenman et al. (2011) rate of exchange should just influence a inflation focusing on national bank's loan fee to the degree that it affects expected expansion.

Inflation likewise gives accurate sign in the associations with exchange rate, which is negative relationship. When in doubt, a country with a consistently lower price rate shows increasing currency appreciation, as per acquiring influence grows in respect to different monetary standards. During the last 50 years of the 20th century, the states with less inflation accomplished low inflation after that. Countries with rising inflation commonly observe deterioration in their currency in connection to the monetary standards of their transaction collaborators (Asari et al. 2011). The financial indicator (DCPS) is reliably negative and noteworthy, which implies that an all-around created budgetary division will prompt a lower financial arrangement rate and subsequently a lower domestic loan fee. An all-around created financial framework offers a more extensive degree for financial approach than an immature framework. Rate of exchange administration or more by and large exchange rate unpredictability, negatively affects (longrun) development when nations are less grown monetarily (Issahaku, et al. 2016). Aghion et al. (2009) found the negative effect of exchange rate instability in less financially developed economies is bigger for enterprises with higher liquidity needs. Additionally, the most surprising effect of DCPS shock on economic growth is found the reaction is negative development yet a later bounce to positive development.

\section{CONCLUSIONS}

Monetary approach donates to sustainable economic development to continue price constancy. Since inflation is essentially a monetary phenomenon, monetary arrangement is the main instrument that can efficiently continue price constancy (stability) in the short and long run. Lower inflation is related with higher long time development. Monetary strategy should unrestraint the quest for price stability with a specific end goal to increment long time economic development. In this study we intend to analyze the relationship of monetary policy, financial development and domestic prices with the economic growth in the context of Pakistan by using time series data from 1980 to 2016 . The results of first model shows that exchange rate and trade is negatively related with economic growth as Pakistan is a developing country its imports are more than from exports, means there is a trade deficit. Because of trade deficits, cash outflow from the country is more from the inflows so growth is declining. Empirical findings show that FDI is positively related with GDP of Pakistan but interest rate is negatively related with the growth as financing costs are brought down, more individuals can acquire more cash. The outcome is that purchasers have more cash to spend, making the economy develop and inflation to increment. The contrary remains constant for rising interest rate. With less spending, the economy moderates and price level diminishes.

There is negative relationship of CPI and EXR with FDI, while saving is positively related with FDI. Low inflation rates promote and stimulate FDI into the region. The negative relationship between two variables shows that foreign direct investment is not utilizing in beneficial and progressive projects or may cannot give the desired result (progress) because of high inflation that can slower the economic growth. As previous studies explain that FDI seems to create vast increments in household savings, with 
no negative ramifications for the outward balance. Higher savings leads to higher investment and reduction in interest rate that increases the FDI that will increase the economic growth.

The result shows that IR, EXR, and financial indicators are negatively related with CPI. Only $M_{2}$ is positively related with CPI. The financial indicators have negative relation with debt. There is a negative and huge connection between EXR scale experience and monetary fences (financial hedges), demonstrating that organizations utilize money subordinates and outside obligation as supports. Result explains that in Pakistan, individuals are more risk averter. Foreign designated debt ought to be adversely identified with the change of the EXR. With a bigger offer of outside named debt relying upon whether the covariance among high price level and the real EXR standard is negative. If the debt rises the growth will reduces or it may explains that there is a low level of growth so the level of debt is increasing that will also rise the currency's exchange rate.

There is negative relation of DCPS (financial development indicator) and CPI with EXR but IR is positively related with exchange rate. A nation with a reliably lower price level displays rising money esteem, as its acquiring influence builds in respect to different monetary standards. A negative yield hole has a tendency to repay the inflationary impact of deterioration by decreasing edges. This is the thing that for the most part happens when the money deterioration is the consequence of negative terms of trade shocks with negative impacts on output.

\section{Reference:}

Aghion, P., Bacchetta, P., Ranciere, R., \& Rogoff, K. (2009). Exchange rate volatility and productivity growth: The role of financial development. Journal of monetary economics, 56(4), 494-513.

Aizenman, J., Hutchison, M., \& Noy, I. (2011). Inflation targeting and real exchange rates in emerging markets. World Development, 39(5), 712-724.

Alguacil, M., Cuadros, A., \& Orts, V. (2004). Does saving really matter for growth? Mexico (19702000). Journal of International Development, 16(2), 281-290.

Allayannis, G., Ihrig, J., \& Weston, J. P. (2001). Exchange-rate hedging: Financial versus operational strategies. American Economic Review, 91(2), 391-395.

Anaripour, J. T. (2011). Study on relationship between interest rate and economic growth by Eviews (2004-2010, Iran). Journal of Basic and Applied Scientific Research, 1(11), 2346-2352.

Anwar, A., Mohsin, A. Q., \& Saboor, A. (2016). Impact of Monetary Policy on Economic Growth in Pakistan: Evaluation and Analysis. Pakistan Journal of Social Sciences (PJSS), 36(1), 131-140.

Arestis, P., \& Demetriades, P. (1997). Financial development and economic growth: assessing the evidence. The Economic Journal, 107(442), 783-799.

Asari, F. F. A. H., Baharuddin, N. S., Jusoh, N., Mohamad, Z., Shamsudin, N., \&Jusoff, K. (2011). A vector error correction model (VECM) approach in explaining the relationship between interest rate and inflation towards exchange rate volatility in Malaysia. World Applied Sciences Journal, 12(3), 49-56.

Asiedu, E. (2002). On the Determinants of Foreign Direct Investment to Developing Countries: Is Africa Different? World Development, 30, 107-119.

Barclay, M. J., \& Smith Jr, C. W. (1995). The maturity structure of corporate debt. the Journal of Finance, 50(2), 609-631.

Barro, R. J. (1991). Economic growth in a cross section of countries. The quarterly journal of economics, 106(2), 407-443.

Bernanke, B., \& Gertler, M. (2000). Monetary policy and asset price volatility (No. w7559). National bureau of economic research. 77-128. Retrieved from http://www.nber.org/papers/w7559.pdf

Bleaney, M., \& Greenaway, D. (2001). The impact of terms of trade and real exchange rate volatility on investment and growth in sub-Saharan Africa. Journal of development Economics, 65(2), 491500 . 
Bosworth, B. P., Collins, S. M., \& Reinhart, C. M. (1999). Capital flows to developing economies: implications for saving and investment. Brookings papers on economic activity, 1999(1), 143180

Crespo-Cuaresma, J., Doppelhofer, G., Feldkircher, M., \& Huber, F. (2016). US monetary policy in a globalized world (No. 5826). CESifo Working Paper. Retrieved from https://www.econstor.eu/handle/10419/130461

D'Adda, C., \& Scorcu, A. E. (1997). Real interest rate and growth: an empirical note. University of Bologna.

Dash, P. (2012). The Relationship between interest rate and exchange rate in India. 1-28. Retrieved from http://oii.igidr.ac.in:8080/jspui/bitstream/2275/214/1/dash_1_.pdf

Economic Survey of Pakistan (2017). Pakistan's economic survey (2016-2017), Planning commissions, Statistical bureau of Pakistan, Policy Wing, Islamabad.

Edwards (1996). The Determinants of the Choice Between Fixed and Flexible Exchange-Rate Regimes. National Bureau of Economic Research (Cambridge, MA) Working Paper No. 5794, 1-26. Retrieved from http://www.nber.org/papers/w5756.pdf

Erceg, C. J., Henderson, D. W., \& Levin, A. T. (2000). Optimal monetary policy with staggered wage and price contracts. Journal of monetary Economics, 46(2), 281-313.

Fama, E. F., \& Gibbons, M. R. (1982). Inflation, real returns and capital investment. Journal of Monetary Economics, 9(3), 297-323.

Fama, E. F., \&Schwert, G. W. (1977). Asset returns and inflation. Journal of financial economics, 5(2), 115-146.

Faulkender, M. (2005). Hedging or market timing? Selecting the interest rate exposure of corporate debt. The Journal of Finance, 60(2), 931-962.

Goldfajn, I. (2000). Public debt indexation and denomination: the case of Brazil. International Journal of Finance \& Economics, 5(1), 43-56.

Goodhart, C. (1989). The conduct of monetary policy. The Economic Journal, 99(396), 293-346.

Grauwe, P. D., \& Polan, M. (2005). Is inflation always and everywhere a monetary phenomenon?. The Scandinavian Journal of Economics, 107(2), 239-259.

Greene, J., \& Villanueva, D. (1991). Private Investment in Developing Countries: An Empirical Analysis, IMF Staff Papers, 38 (1), 33-41

Habib, M. M., Mileva, E., \&Stracca, L. (2017). The real exchange rate and economic growth: revisiting the case using external instruments. Journal of International Money and Finance, 73, 386-398.

Hassan, M. S., Wajid, A., \&Kalim, R. (2017). Factors affecting trade deficit in Pakistan, India and Bangladesh. EconomiaPolitica, 34(2), 283-304.

Hye, Q. M. A., \& Lau, W. Y. (2015). Trade openness and economic growth: empirical evidence from India. Journal of Business Economics and Management, 16(1), 188-205.

lacoviello, M. (2005). House prices, borrowing constraints, and monetary policy in the business cycle. American economic review, 95(3), 739-764.

lamsiraroj, S., \& Ulubaşoğlu, M. A. (2015). Foreign direct investment and economic growth: A real relationship or wishful thinking?.Economic Modelling, 51, 200-213.

Issahaku, H., Harvey, S. K., \& Abor, J. Y. (2016). Does development finance pose an additional risk to monetary policy?. Review of Development Finance, 6(1), 91-104.

Levine, R. (1999). Financial development and economic growth: views and agenda. The World Bank.

McCarthy, J. (2007). Pass-through of exchange rates and import prices to domestic inflation in some industrialized economies. Eastern Economic Journal, 33(4), 511-537.

Mussa, M. (1977). The exchange rate, the balance of payments and monetary and fiscal policy under a regime of controlled floating. In Flexible Exchange Rates and Stabilization Policy Palgrave Macmillan UK. 97-116.

Ratanapakorn, O., \& Sharma, S. C. (2007). Dynamic analysis between the US stock returns and the macroeconomic variables. Applied Financial Economics, 17(5), 369-377.

Ratnasari, A., \& Widodo, T. (2017). Exchange Market Pressure and Monetary Policies in ASEAN5. MPRA $1-17$ 
Rodrik, D. (2007). The real exchange rate and economic growth: theory and evidence. Online available at: http://citeseerx.ist.psu.edu/viewdoc/download?doi=10.1.1.641.4710\&rep=rep1\&type=pdf (accessed on 23rd December, 2018).

Taylor, C. T. (2000). The impact of host country government policy on US multinational investment decisions. The World Economy, 23(5), 635-647.

Van Wijnbergen, S. (1982). Stagflationary effects of monetary stabilization policies: A quantitative analysis of South Korea. Journal of Development Economics, 10(2), 133-169. 